THE COMMITTEE SYSTEM FOR COMPETITIVE BIDS IN LOCAL GOVERNMENT

ISSN 1727-3781

2009 VOLUME 12 No 2 


\section{THE COMMITTEE SYSTEM FOR COMPETITIVE BIDS IN LOCAL GOVERNMENT*}

P Bolton ${ }^{* *}$

\section{Introduction}

Over the last decade the procurement procedures of government have received increasing attention in the courts and academic literature. As yet, however, there has been little analysis of the committee system for competitive bids created in legislation for the procurement of goods and services by government. ${ }^{1}$ One of the reasons for this is that it is only after organs of state, and in particular municipalities, have begun to implement the bid committee system in their day-to-day practices that it is clear that problems are arising. In recent months, the courts have increasingly been faced with issues revolving around the implementation of the bid committee system. This article is timely in that it will critically analyse the relevant legislative provisions in light of all the cases that have thus far involved the bid committee system at local government level. Even though legislation for national and provincial government provides for the use of the committee system for competitive bids, and in certain respects the relevant provisions correspond with those that apply to local government, there are significant differences. A thorough analysis and comparison of the provisions that apply at all three levels of government will result in too lengthy an article. The committee system for competitive bids at national and provincial level will accordingly be examined elsewhere and this article will be confined to local government. Most of the cases that have thus far

* This material is based upon work supported financially by the National Research Foundation.

** Associate Professor of Law, University of the Western Cape, South Africa.

1 For an overview of the committee system for competitive bids in local government, see Steytler and De Visser Local Government Law 14-23 to 14-29. 
dealt with the bid committee system, moreover, do so from a local government perspective.

As background, an overview will be given of the legal framework for public procurement at local government level. In doing so, the focus will be on the Constitution of the Republic of South Africa, ${ }^{2}$ in particular section 217 , the Preferential Procurement Policy Framework Act, ${ }^{3}$ and Regulations, ${ }^{4}$ the Local Government: Municipal Finance Management Act (MFMA) ${ }^{5}$ and the Municipal Supply Chain Management Regulations (MSCM Regulations). ${ }^{6} \mathrm{Next}$, the use of competitive bidding, also generally known as a public call for tenders, and the committee system will be discussed. The roles of each committee in the bidding process will be examined, including the rules that apply to the composition of each committee. Attention will also be given to the supervisory role of the municipal manager over the different committees. The relevant legislative provisions will be critically analysed and reference will be made to applicable case law. Of particular interest will be the recent case of Actaris South Africa (Pty) Ltd v Sol Plaatje Municipality, Intelligent Metering Systems (Pty) Ltd. ${ }^{7}$ The court in this case interpreted a number of the legislative provisions dealing with the roles and composition of the different committees.

2 Constitution of the Republic of South Africa 1996. Hereafter the Constitution.

3 Act 5 of 2000. Hereafter the Procurement Act.

4 Preferential Procurement Regulations GG 22549 of 10 August 2001.

5 Act 56 of 2003.

6 Local Government: Municipal Finance Management Act (56/2003): Municipal Supply Chain Management Regulations GG 27636 of 30 May 2005. There is, of course, also other legislation that applies to local government and that would be relevant for public procurement, eg, the Local Government: Municipal Systems Act 32 of 2000, as amended by Act 44 of 2003, the Local Government Laws Amendment Act 51 of 2002, and the Local Government: Municipal Structures Act 117 of 1998, as amended by Act 1 of 2003. There are, moreover, the Promotion of Access to Information Act 2 of 2000, the Promotion of Administrative Justice Act 3 of 2000 and the Prevention and Combating of Corrupt Activities Act 12 of 2004 that also apply to public procurement procedures. A detailed examination of this legislation falls outside the scope of the article, but where relevant reference may be made thereto.

7 Actaris South Africa v Sol Plaatje Municipality, Intelligent Metering Systems (1357/2007) [2008] ZANCHC 73 (12 December 2008). Hereafter Actaris South Africa (Pty) Ltd case. 


\section{The legal framework for public procurement in local government}

\subsection{Constitution}

The legal regulation of public procurement in South Africa is constitutionalised. Section 217 of the Constitution provides that organs of state, and this includes municipalities and municipal entities, ${ }^{8}$ must contract for goods or services in accordance with a system that is fair, equitable, transparent, competitive and cost-effective. Municipalities and municipal entities are not prevented, however, from implementing a procurement policy that provides for categories of preference in the award of contracts and the advancement of persons or categories of persons disadvantaged by unfair discrimination. Such preferential procurement policy must be in accordance with national legislation that provides a framework for its implementation. Provision is therefore made in the Constitution for the use of procurement as a policy / empowerment tool. The principles of fairness, value for money (competitiveness and cost-effectiveness) and transparency are, furthermore, internationally regarded as the cornerstone of good procurement practice. ${ }^{9}$ Their inclusion in the Constitution is therefore commendable, because organs of state are bound by the most essential elements of a good procurement system whenever they contract for goods or services. Sections 215-219 of the Constitution further impose a responsibility on the National Treasury to introduce norms and standards within government, thereby ensuring transparency and expenditure control measures.

8 See s 217(1) which refers to organs of state in the national, provincial and local sphere of government. See also s 239 of the Constitution for the definition of an organ of state. A municipal entity is defined in s 1 of the Municipal Systems Act as "(a) a private company [established by one or more municipalities or in which one or more municipalities have acquired or hold an interest]; (b) a service utility; or (c) a multi-jurisdictional service utility". A service utility, in turn, refers to a body established under $\mathrm{s} 86 \mathrm{H}$ of the Act and a multijurisdictional service utility refers to a body established under s 87 of the Act. The notion of ownership control by the government therefore appears to be the overriding criterion.

9 See the Government Procurement Agreement at WTO 1996 www.wto.org/ and the Model Law on Procurement of Goods, Construction and Services at UNCITRAL 1994 www.uncitral.org/ 


\subsection{Procurement Act and Regulations}

The Procurement Act has been enacted to provide a framework for the use of procurement as a policy tool as required by section 217 of the Constitution. ${ }^{10}$ The Act applies to a list of organs of state, which includes municipalities. ${ }^{11}$ The Minister of Finance may recognise any other institution included in the definition of an organ of state in section 239 of the Constitution. ${ }^{12}$ As yet, however, there has been no recognition of municipal entities as organs of state for the purposes of the Procurement Act. ${ }^{13}$ They are, accordingly, not subject to the Procurement Act and Regulations. Municipalities must (however) use the framework provided in the Act and Regulations and may not adopt a more generous preferential procurement policy unless the Minister of Finance directs otherwise. ${ }^{14}$ The Procurement Act and Regulations create a point system for the evaluation and adjudication of bids in terms of which points are awarded on the basis of price (sometimes also functionality) and the attainment of two specific goals for preference purposes. First, preference may be afforded to persons or categories of persons historically disadvantaged by unfair discrimination on the basis of race, gender or disability, and second for the implementation of government's Reconstruction and Development (RDP) Programme. ${ }^{15}$ For contracts between R30 000 and R500 000 the 80/20 point system applies and in terms of it bidders are awarded points out of 80 for price and points out of 20 for preference. For contracts above R500 000 the 90/10 point system applies, with points out of 90 for price and points out of 10 for

10 The Procurement Act and Regulations are currently (7 May 2009) in the process of being redrafted with the aim to bring them more in line with the Broad-Based Black Economic Empowerment Act 53 of 2003 (BBBEEA).

11 See $\mathrm{s} 1$ (iii) of the Act.

12 S 1(iii)(f) of the Procurement Act.

13 This information is based on a search conducted on LexisNexis, Butterworths databases available at http://butterworths.uwc.ac.za/ See also Penfold and Reyburn "Public Procurement" 25-14.

14 Reg 2(2).

15 S 2(1)(d) of the Procurement Act. See further reg 17(3) which lists a number of RDP goals which include, inter alia, the promotion of South African owned enterprises, the creation of new jobs or the intensification of labour absorption, and the promotion of enterprises located in rural areas. 
preference. A contract must be awarded to the bidder scoring the highest points in terms of the relevant point system unless there are objective criteria that justify the award of the contract to another bidder. ${ }^{16}$

\subsection{MFMA and MSCM Regulations}

At local government level specific legislation deals with financial management and expenditure control as required by the Constitution. The MFMA, inter alia, aims "[t]o secure sound and sustainable management of the financial affairs of municipalities and other institutions in the local sphere of government". ${ }^{17}$ Chapter 11 of the Act deals with supply chain management (SCM) and provides that each municipality and each municipal entity must have and implement a supply chain management policy (SCMP) that falls within the framework for SCM created in the Act. ${ }^{18}$ An SCMP must provide for a system of SCM that is fair, equitable, transparent, competitive and cost-effective, ${ }^{19}$ thus reiterating the principles in section 217 of the Constitution. An SCMP must also comply with a prescribed regulatory framework, which must cover the list of matters specified in section 112(1) of the MFMA. Such regulatory framework must further be fair, equitable, transparent, competitive and cost-effective. ${ }^{20}$

The framework for an SCMP has been captured in the MSCM Regulations issued by the National Treasury in 2005. In terms of the Regulations an SCMP must make provision for effective systems for demand management, acquisition management, logistics management, disposal management, risk management, and performance management. ${ }^{21}$ The focus of this article will be on the rules that apply to acquisition management because this is where the committee system for competitive bids comes into play. In terms of the

16 For more detailed discussion and analysis see Bolton Government Procurement in South Africa ch 10. See also Steytler and De Visser (n 1) 14-10 to 14-13; Penfold and Reyburn (n 13); Watermeyer 2000 PPLR; Gounden Affirmative Procurement Policy.

17 See the Preamble to the Act.

$18 \mathrm{~S} 111$.

19 S 112(1).

20 S 112(2).

$21 \operatorname{Reg}$ 9(b). 
Regulations an SCMP must provide for four types of acquisition / procurement: petty cash purchases for contracts up to R2000; written or verbal quotations for contracts over R2 000 and up to R10 000; formal written price quotations for contracts over R10 000 and up to R200 000; and competitive bidding for contracts over R200 000 and long term contracts, that is, contracts with a duration of more than one year. ${ }^{22}$ Where competitive bidding is used the committee system applies and this will be the focus in the next paragraph and the rest of the article. It is important to note, however, that an SCMP may allow the accounting officer, who is the municipal manager in the case of a municipality, ${ }^{23}$ to apply the committee system also to formal written price quotations. $^{24}$

\section{Competitive bidding and the committee system}

As noted, a municipality must make use of competitive bidding for contracts over R200 000 as well as for long term contracts. A competitive bidding process generally consists of different stages and in terms of the MSCM Regulations, an SCMP must provide for procedures for each of the stages, that is, the compilation of bid documentation, the public invitation of bids, site meetings or briefing sessions where necessary, the handling of bids after submission, the evaluation of bids and the award of contracts, and the administration of contracts and proper record keeping. ${ }^{25}$ A committee system must be in place to oversee the different stages and must consist of at least a bid specification committee, a bid evaluation committee and a bid adjudication

22 Reg 12(1) read with reg 1.

$23 \mathrm{~S} 60$ of the MFMA provides that "[t]he municipal manager of a municipality is the accounting officer of the municipality for the purposes of this Act, and, as accounting officer, must - (a) exercise the functions and powers assigned to an accounting officer in terms of this Act; and (b) provide guidance and advice on compliance with this Act to - (i) the political structures, political office-bearers and officials of the municipality; and (ii) any municipal entity under the sole or shared control of the municipality".

24 Reg 26(3).

25 Reg 20. 
committee ${ }^{26}$ The municipal manager (as accounting officer of the municipality) must appoint the members of the different committees and no councillor may be a member or attend as an observer. ${ }^{27}$ An SCMP must also provide for the appointment by the municipal manager of an attendance or oversight process by a neutral or independent observer when this is necessary to ensure fairness and transparency. ${ }^{28}$ An SCMP may further, as noted above, allow the municipal manager to apply the committee system to formal written price quotations. ${ }^{29}$ Regulations 27, 28 and 29 then deal with the different committees.

\subsection{Bid specification committee}

\subsubsection{Legislative provisions}

The bid specification committee (BSC) is responsible for the compilation and drafting of specifications for the procurement of goods and services by the municipality or municipal entity. ${ }^{30}$ The committee must consist of one or more officials of the municipality or municipal entity and "preferably" the manager responsible for the function involved. ${ }^{31}$ The committee may also, when appropriate, include members who are external specialist advisors. ${ }^{32}$ Persons, advisors or corporate entities who participate in the BSC or the directors of such corporate entities are, however, prohibited from bidding for any resulting contracts. ${ }^{33}$ The bid documentation prepared by the BSC must take into account the General Conditions of Contract, any Treasury Guidelines and the requirements of the Construction Industry Development Board if the bid relates to the construction, upgrading or refurbishment of buildings or infrastructure..$^{34}$ It must further require sufficient information from bidders in their bids, in particular

$26 \operatorname{Reg} 26(1)(\mathrm{a})$.

27 Reg 26(1)(b) read with s 117 of the MFMA. See Ortlieb \& Associates $v$ Camdeboo Local Municipal Council and Others 2005 JDR 0408 (E) where the court set aside the award of a bid because a councillor chaired the bid committee.

$28 \operatorname{Reg} 26(1)(c)$.

$29 \operatorname{Reg} 26(3)$.

$30 \operatorname{Reg} 27(1)$.

31 Reg 27(3).

$32 \operatorname{Reg} 27(3)$.

33 Reg 27(4).

$34 \operatorname{Reg} 21(\mathrm{a})$. 
the identification of the bidder and information relating to tax matters; whether the bidder, any of its directors, managers, principal shareholders or stakeholder, or spouse, child or parent of the bidder or directors, managers, principal shareholders or stakeholder is or has been in the service of the state in the past 12 months. ${ }^{35}$ Bid documentation must require bidders to "declare any conflict of interest they may have in the transaction for which the bid is submitted". ${ }^{36}$ Additional information must further be provided where the value of the transaction is expected to exceed R10 million, that is, (i) the bidder's annual audited financial statements for the past three years (or since establishment if established in the last three years); (ii) a certificate stating that the bidder has no undisputed commitments for municipal services towards a municipality or other service provider in respect of which payment is overdue for more than 30 days; (iii) particulars of any contracts awarded to the bidder by an organ of state in the past 5 years (and particulars with regard to any material noncompliance or dispute regarding the execution of such contract); (iv) a statement whether it is expected that any portion of the goods or services will be sourced from outside South Africa and if so, the portion and whether payment for that portion will be transferred outside South Africa. ${ }^{37}$ The documentation must also stipulate that disputes must be resolved by means of mutual consultation or mediation and as a last resort a South African court of law. ${ }^{38}$

Insofar as the actual drafting of specifications is concerned, the MSCM Regulations provide that specifications must be drafted in an unbiased manner to allow all potential bidders to participate. ${ }^{39}$ Specifications "must take account of any accepted standards such as those issued by Standards South Africa, the International Standards Organisation, or an authority accredited or recognised by the South African National Accreditation System with which the equipment

35 Reg 13.

36 Reg 21(c).

37 Reg 21(d).

38 Reg 21(e).

$39 \operatorname{Reg} 27(2)(a)$. 
or material or workmanship should comply". ${ }^{40}$ Specifications must, where possible, be described in terms of performance required rather than descriptive characteristics for design. ${ }^{41}$ They "may not create trade barriers in contract requirements in the forms of specifications, plans, drawings, designs, testing and test methods, packaging, marking or labeling or conformity certification". ${ }^{42}$ Specifications "may not make reference to any particular trade mark, name, patent, design, type, specific origin or producer unless there is no other sufficiently precise or intelligible way of describing the characteristics of the work, in which case such reference must be accompanied by the words [sic] 'equivalent"'. ${ }^{43}$ They "must indicate each specific goal for which points may be awarded in terms of the point system set out in the [SCMP] of the municipality or municipal entity" ${ }^{44}$ including the criteria required by the Procurement Act, BBBEEA and the Construction Industry Development Board Act. ${ }^{45}$ The municipal manager must approve the specifications prior to the publication of the invitation for bids. ${ }^{46}$

\subsubsection{Analysis}

$40 \operatorname{Reg} 27(2)(\mathrm{b})$.

$41 \operatorname{Reg} 27(2)(\mathrm{c})$.

$42 \operatorname{Reg} 27(2)(d)$.

$43 \operatorname{Reg} 27(2)(d)$.

$44 \operatorname{Reg} 27(2)(\mathrm{f})$.

45 Act 38 of 2000. Reg 21(b) read with reg 1.

46 Reg 27(2)(g). See further National Treasury 2006 www.finance.gov.zal par 2, which stipulates that that if and when required to do so, the bid adjudication committee may consider for approval the recommendations of the BSC. This may be done to ensure that the need for the particular goods or services forms part of the strategic goals and objectives as stated in the municipality's Integrated Development Plan; a suitable and unbiased specification is compiled for the particular requirement; proper terms of reference are drafted for the service required clearly indicating the scope of the requirement, the ratio between price and functionality, the evaluation criteria and their weights and values; strategic sourcing principles were applied and that the market was properly researched and analysed; the necessary funds are available in the approved budget; where appropriate, Special Requirements and Conditions of Contract are specified in addition to the General Conditions of Contract; the preference point system and appropriate goals are identified and the points allocated for these goals are consistent with the requirements of the Procurement Regulations; and where appropriate, ranges have been set which indicate the breakdown of points or the percentages as provided for in the relevant sliding scales for the selected specified goals. 
The provisions relating to the drafting of specifications would generally ensure the fair treatment of bidders and competition that is sufficiently wide. Slanted specifications would clearly defeat fairness, transparency and competition and the use of trade names, etc. may unnecessarily limit competition. Transparency in the award of points for the attainment of specific goals further promotes informed participation by interested parties and enhances the integrity of the bid process. It is, of course, also important to guard against bias and the appearance of bias in the bidding process. Requiring bidders to declare any conflict of interest they may have in the transaction for which the bid is submitted, and to declare whether they or certain persons linked to them are or have been in the service of the state serves this purpose. Preventing outside persons or entities who participate in the BSC as specialist advisors from bidding for contracts also guards against bias and the appearance of bias. On a critical note, however, the Regulations stipulate that the manager responsible for the function involved should "preferably" be a member of the BSC. Reference is further made to "officials" of the municipality or municipal entity without specifying from which departments these officials should be. It is submitted that the Regulations should be more specific with regard to the membership of the BSC and make it compulsory for at least one of the members to be from the relevant department requiring the goods or services. Bidders will prepare their bids based on the specifications and as will be explained shortly, the bid evaluation committee is bound by the specifications advertised and must evaluate bids in accordance with the specifications. The drafting of the specifications is therefore of utmost importance and it is simply logical for the members of the BSC to be composed of at least one member from the relevant department who is familiar with the department's needs. Such member should then, where possible, be the manager of the relevant department. Further reasons for this recommendation will emerge from the discussion that follows.

\subsection{Bid evaluation committee}


In dealing with this committee the relevant legislative provisions will first be discussed. An analysis will then follow of the provisions relating to the composition of the committee, the binding nature of the bid specifications advertised and the disqualification of bidders.

\subsubsection{Legislative provisions}

The bid evaluation committee (BEC) is responsible for the evaluation of bids submitted in response to a public invitation for bids. ${ }^{47}$ The committee must, as far as possible, consist of officials from the departments requiring the goods or services and at least one SCM practitioner of the municipality or municipal entity. ${ }^{48}$ The evaluation of bids must be done in accordance with the specifications for the particular procurement and the points system as set out in the municipality or municipal entity's SCMP and the prescripts of the Procurement Act. ${ }^{49}$ The committee must evaluate the "ability" of each bidder to execute the contract. ${ }^{50}$ Even though the meaning of the term "ability" is not defined in the Regulations, depending on the nature of the contract, it would generally require a consideration of: the nature, quality and reliability of the product or service to be rendered; ${ }^{51}$ the experience and track record of the bidder; ${ }^{52}$ the technical knowledge and capacity of the bidder; the possession of appropriate licenses and permits; ${ }^{53}$ the ability of the bidder to comply with the

47 On the rules that apply to such public invitation, eg, methods of publication, time periods and closing date, and the handling, opening and recording of bids, see reg 22 and 23 . See also Bolton (n 16) 155-156, 192-193; Steytler and De Visser (n 1) 14-25 to 14-26.

48 Reg 28(2).

$49 \operatorname{Reg} 28(1)(a)$.

50 Reg 28(b).

51 Trepte Public Procurement in the EC 162.

52 lbid.

53 Schooner 2004 PPLR 213. 
delivery schedule; ${ }^{54}$ the bidder's record of business ethics and integrity; ${ }^{55}$ and the availability of tools or equipment for the bidder's use. ${ }^{56}$ It would, of course, also be important to take into account the price of the different bids and in doing so, to have regard to the overall price, namely, running costs, maintenance costs and rates charged per unit. ${ }^{57}$ The committee may also have regard to the commitment of the bidder with respect to spare parts and after-sales service; ${ }^{58}$ the number of staff employed by the bidder; ${ }^{59}$ and where relevant, the qualifications and competence of the personnel of the bidder. ${ }^{60}$ The committee would, moreover, have to determine the bidder's entitlement to preference in terms of the applicable point system and the preference goals advertised. Once a preferred bidder is identified based on the applicable point system, the committee must check whether such bidder's municipal rates and taxes and municipal service charges are in arrears. ${ }^{61}$ Should this be the case, the committee would elect the next best preferred bidder and follow the same procedure, that is, checking tax related matters, etc. The committee must then submit to the bid adjudication committee (BAC) a report and recommendations regarding the award of the bid or any other related matter. ${ }^{62}$ As a rule, the BEC must recommend the highest scoring bidder as preferred bidder and if not, it must justify its recommendation to the BAC. ${ }^{63}$ The BEC may, moreover, conclude that no award should be made, but again it would have to provide reasons to the BAC for this. ${ }^{64}$ Overall, the municipal manager retains a

54 Ibid.

55 Ibid.

56 Trepte (n 51) 162.

57 This is also referred to as life cycle costing.

58 Trepte (n 51) 162.

59 Ibid, 54.

60 Ibid, 162.

61 Reg 28(c).

$62 \operatorname{Reg} 28(d)$.

63 See s 2(1)(f) of the Procurement Act and reg 9 of the Procurement Regulations.

64 Reg 10(4) of the Procurement Regulations makes provision for the cancellation of a bid process prior to the award of bids if "(a) due to changed circumstances, there is no longer [a] need for the goods or services tendered for; or (b) funds are no longer available to cover the total envisaged expenditure; or (c) no acceptable tenders are received". "An acceptable tender" is defined in s 1 of the Procurement Act as "any tender which, in all respects, complies with the specifications and conditions of tender as set out in the tender document". 
supervisory role over the BEC and may at any stage refer the BEC's recommendation back to it for reconsideration. ${ }^{65}$

\subsubsection{Composition of the BEC}

The MSCM Regulations contain no provisions prohibiting members of the BSC from being members of the BEC. Strictly speaking therefore this is allowed. The National Treasury, ${ }^{66}$ however, recommends that whenever possible membership of the BSC and BEC should not overlap. It is, furthermore, logical for the members of the BEC to be composed of officials of the department requiring the goods or services as required by the Regulations. ${ }^{67}$ The court in Actaris South Africa (Pty) $L t d^{68}$ emphasised this. The municipality in this case had concluded a three-year contract with Actaris Measurement and Systems (Pty) Ltd (Actaris M \& S), an associate of the applicant (Actaris), for the supply of pre-payment vending software and hardware for the provision of electricity. During the three year period, and with the agreement of the municipality, Actaris replaced Actaris $M \& S$ as service provider and when the contract came to an end, the parties agreed that it would run on a month-to-month basis. In the meantime, the municipality called for bids for four different contracts. Khatima Engineering Services (KES) was appointed to conduct a technical evaluation of the bids and in its initial report it recommended four companies for short-listing, that is, Actaris, IMS, Netgroup and Conlog. KES then asked the short-listed companies for further information and conducted site visits. Representations were made by the companies and thereafter KES recommended the award of three of the four contracts to IMS. KES did not make any recommendation with respect to one of the contracts (relating to maintenance and management) because the services under this contract would effectively be provided in the execution of the other contracts by IMS. The cost and management accountant of the municipality then calculated the price of

65 Reg 29(6) of the MSCM Regulations.

66 National Treasury 2005 www.treasury.gov.za/ par 4.5.5.2.1.

$67 \operatorname{Reg} 28(2)(a)$.

68 See $n 7$ supra. 
each bid and the points scored for functionality, price and specific contract participation goals. The BEC and BAC of the municipality "considered" the bids and both recommended IMS as the preferred bidder for the three contracts. The municipal manager made the final decision and awarded the contracts to IMS.

Actaris applied to court for the review and setting aside of the decisions of the municipality to award the contracts to IMS and asked the court to refer the adjudication of the bids back to the municipality for reconsideration in accordance with section 2(1)(c) of the Procurement Act and Regulations, and paragraph 27(1) of the municipality's SCMP. It argued, inter alia, that none of the members of the BEC had technical expertise and that it was unclear whether the committee was, as far as possible, composed of "officials from departments requiring the goods or services" as required by the municipality's SCMP and the MSCM Regulations. ${ }^{69}$ It argued that there was non-compliance with section 6(2)(b) of the Promotion of Administrative Justice Act $^{70}$ in that a "mandatory and material procedure or condition prescribed by an empowering provision was not complied with". Actaris therefore effectively relied on Regulation 28(2)(a) of the MSCM Regulations which provides, insofar as relevant, that "[a BEC] must as far as possible be composed of ... officials from departments requiring the goods or services". The municipality argued that Actaris was disqualified from further consideration for the one contract because it did not meet the $60 \%$ threshold for functionality, which was one of the bid conditions. Actaris was also not awarded the other two contracts because it was outscored by IMS.

The court found that even though two persons from the relevant electricity department, that is, the Chief Electrical Engineer (seconded to the municipality by Eskom) and the Chief Superintendent: Testing and Metering were both

69 Par 35, emphasis original.

70 Act 3 of 2000. 
present at the meeting of the BEC, they were not members of the committee. They had no voting power and could not take part in the decision-making process. There was also no reason why it was not possible in terms of the municipality's SCMP for at least one of them to be members of the BEC. The municipality further failed to provide any explanation as to why any of the other members of the electricity department were not members of the BEC. The result was that none of the members of the BEC were officials from the department. ${ }^{71}$ The court held that the words "must as far as possible" in paragraph 27(2) of the SCMP, which reiterates Regulation 28(2) of the MSCM Regulations, were peremptory:

\begin{abstract}
These words must be read in context and the intention quite clearly was that, should such officials be available for appointment as members, at least one 'must' serve as a member for the purpose of at least those meetings where decisions will be taken and recommendations will be made which would affect the particular department. $^{72}$

There is [also] absolutely no reason why the composition of these committees could not be revised from time to time, depending on the nature of the [bids] to be considered and the departments to be affected, and the provisions of the policy and the regulations cannot be interpreted in any other way. ${ }^{73}$
\end{abstract}

The court therefore afforded peremptory status to paragraph 27(2) of the SCMP and Regulation 28(2)(a) of the MSCM Regulations with respect to the membership of the BEC and that membership must hail from the department requiring the goods or services. This can be commended. The rules relating to the appointment of BEC members are there to ensure that, amongst other things, the department requiring the goods or services has an opportunity to participate in the decision-making process since it is directly affected by the outcome of the award. It is, as the court stated, crucial for the relevant department to play a role in the decision making process. The officials of the relevant department would be best placed to assess the merits of the bids and their inclusion would promote the principles underlying bid processes.

71 Par 42-44.

72 Par 48, emphasis original.

73 Par 50. 


\subsubsection{The binding nature of the specifications}

The BEC is, as noted, bound by the specifications for the particular procurement; bids must be evaluated in accordance with the specifications. ${ }^{74}$ This is, of course, important to ensure the fair treatment of bidders and compliance with the principle of transparency. The whole rationale behind competitive bidding may be defeated where changes are made to the specifications, conditions or the rules that have been laid down for conducting the process such as qualification, selection or adjudication criteria, or procedural rules relating to formalities for bids. The precise impact of such changes is examined in greater detail below ${ }^{75}$ when attention is given to the supervisory role of the municipal manager over the three committees. The rationale behind competitive bidding would, furthermore, be defeated if after a public call for bids, a municipality is allowed to conclude a contract(s) with the preferred bidder that differ from the specifications advertised.

In Nelson Mandela Bay Municipality v Afrisec Strategic Solutions (Pty) Ltd ${ }^{76}$ the court, at the instance of the municipality, set aside agreements concluded with the preferred bidder (Afrisec) on the ground that they exceeded the scope of the bid invitation and the specifications advertised. The municipality had called for bids for an asset risk analysis and design of a security master plan for the municipality. A main agreement was concluded with Afrisec and thereafter a number of "scope of work agreements" (SOW's). When the municipality subsequently called for bids for the provision of security alarm systems and goods, Afrisec threatened the municipality with litigation unless the municipality withdrew the invitation. Afrisec argued that it had, in terms of the main agreement with the municipality, certain rights with regard to not only the analysis, design and monitoring of the security master plan, but also its implementation. The court agreed with the municipality that only one of the

74 MSCM reg 28(1)(a).

75 Par 3.4.

76 Nelson Mandela Bay Municipality v Afrisec Strategic Solutions 2008 JDR 1014 (SE).

$72 / 168$ 
agreements concluded with Afrisec (SOW 1) conformed to the bid invitation and confirmed its validity. All the other agreements, including the main agreement, exceeded the scope of the bid invitation, the bid submitted by Afrisec and the letter accepting such bid. Afrisec submitted a bid of about R2.7 million, but at the date of the application to court the final agreements were already in the region of R12 million. In light thereof the court found that the conclusion was "inescapable": ${ }^{77}$ the relevant agreements were invalid because they exceeded the scope of the original bid. ${ }^{78}$ The municipality's bid invitation did not state that the invitation was for the implementation of the general security plan. Afrisec's bid price was for the design of the security plan in the sum of R803 000 and R80 000 per month for monitoring. Its bid price did not contain a fixed or ascertainable amount for the implementation of the general security plan. The municipality moreover accepted Afrisec's bid for the analysis and design of a security plan and not for its implementation. ${ }^{79}$

Bid specifications can, of course, also be said to create a legitimate expectation on the part of bidders that the municipality calling for bids will consider and evaluate bids based on the specifications advertised. The Supreme Court of Appeal in Metro Projects CC and Another v Klerksdorp Local Municipality and Others $^{80}$ stressed the value of municipalities abiding by the criteria (specifications) provided in bid documents. In this case, a contract was awarded to a bidder who had been given an opportunity by a municipal official to supplement its bid after the closing date to ensure acceptance. The court held that this deception "stripped the [bidding] process of an essential element of fairness: the equal evaluation of [bids]. Where subterfuge and deceit subvert the essence of a [bidding] process, participation in it is prejudicial to every one

77 Par 20.

78 Slightly different reasoning was applied by the court with respect to one of the agreements (SOW 2) because the dispute with regard to SOW 2 was based on different grounds. Afrisec had argued that a different bid process preceded SOW 2. The agreement was nevertheless set aside because it too exceeded the scope of the bid invitation. See par 2526 of the case.

79 For detailed discussion and analysis of the case, see Bolton 2009 JSAL.

80 Metro Projects v Klerksdorp Local Municipality 20041 SA 16 (SCA). 
of the competing [bidders] whether it stood a chance of winning the [bid] or not". ${ }^{81}$ The Procurement Act also defines an "acceptable tender" as one that "in all respects complies with the specifications and conditions of tender as set out in the tender document". ${ }^{82}$ In this respect, the court admitted that "[t]here are degrees of compliance with any standard and it is notoriously difficult to assess whether less than perfect compliance falls on one side or the other of the validity divide". In the present case, however, the court found that "there is no difficulty. The offer put before [the decision-making body] was not the one made in [the second respondent's bid]. It was not one elicited by the specifications and [bid conditions]". ${ }^{83}$ The award of the contract to the second respondent was as a result set aside.

\subsubsection{Disqualification of bidders}

The MSCM Regulations, as noted, provide that the preferred bidder's payment of municipal rates and taxes etc. must be checked. ${ }^{84}$ This is important because the non-payment of these may result in the disqualification of such bidder. Regulation 38(1)(d)(i) provides that an SCMP must enable a municipal manager to reject any bid from a bidder whose municipal rates and taxes and municipal service charges are in arrears for more than three months. The courts have, however, indicated that the decision to disqualify or recommend the disqualification of a bidder for the non-payment of taxes should not be taken lightly. In Imvusu Trading 134 CC and Another v Dr Ruth Mompati District Municipality and Others ${ }^{85}$ the municipality invited bids for the second time for the provision of water metered connections and precast toilets for 450 stands in Huhudi after its first call for bids attracted no interest. The BEC recommended to the BAC that the bid be awarded to the applicant even though it was ranked second, because the first ranked bidder, the fifth respondent, furnished an

\footnotetext{
81 Par 14.

82 Par 15.

83 Par 15

84 Reg 28(c).

85 Imvusu Trading 134 v Dr Ruth Mompati District Municipality 2628/08 [2008] ZANWHC 46 (20 November 2008).
} 
outdated tax clearance certificate. The BAC, however, "sent the documentation back [to the BEC]" in order for the fifth respondent's tax status to be verified. ${ }^{86}$ The fifth respondent was then allowed to replace its outdated certificate with a new one and was awarded the bid. The applicants argued that the conduct of the bid committees contravened section 217 of the Constitution in that the process was not fair, transparent, competitive and cost-effective. They accordingly asked the court to review and set aside the award of the bid to the fourth and fifth respondents. ${ }^{87}$ The court referred to a number of Supreme Court of Appeal decisions which confirm the following principles: a tender board may condone some deficiencies; ${ }^{88}$ a bona fide mistake should not in and of itself disqualify a bidder; ${ }^{89}$ substance should prevail over form; ${ }^{90}$ a distinction should be drawn between a material factor and the evidence needed to prove that factor; ${ }^{91}$ regard must be had to the facts as a whole in the context of the applicable legislation and the principles involved; and the words "acceptable tender" in the Procurement Act involves a consideration of the degree of compliance with bid conditions. ${ }^{92}$ The court then held that in the present case there was no doubt that the fifth respondent's tax clearance certificate was at all times in order and that the only problem was that it failed to provide proof thereof at the closing date for bids. The court held that allowing the fifth respondent to supply proof of its tax status amounted to the correction of a bona fide mistake, which the fifth respondent had made and did not render the process unfair, uncompetitive or not transparent. ${ }^{93}$

86 Par 5.

87 Par 6.

88 Referring to Millennium Waste Management $v$ Chairperson Tender Board: Limpopo Province [2008] 2 All SA 145 (SCA) par 58.

89 Referring to Millennium Waste Management $v$ Chairperson Tender Board: Limpopo Province [2008] 2 All SA 145 (SCA) par 58; Total Computer Services v Municipal Manager, Potchefstroom Local Municipality 20084 SA 346 (T).

90 Referring to Minister of Social Development v Phoenix Cash \& Carry - Pmb [2007] 3 All SA 115 (SCA).

91 Ibid.

92 Par 7 and 8. Referring to Metro Projects v Klerksdorp Local Municipality 20041 SA 16 (SCA) par 15.

93 Par 16 and 17. 
The court in Actaris South Africa (Pty) Ltd also confirmed the functions of the different parties and committees involved in that case with respect to the (general) disqualification of bidders. ${ }^{94}$ As explained, Actaris had been disqualified from the award of one of the contracts on the ground that it failed to meet the functionality requirement for the contract as stipulated in the bid conditions. The court noted that neither KES (which was appointed to conduct a technical evaluation of the bids) nor the cost and management accountant (who calculated the price of each bid and the points scored for functionality, price and specific contract participation goals) had the power or authority to disqualify bidders. KES had to recommend the award of technical points and the cost and management accountant had to copy the overall points to a spreadsheet to enable the BEC and BAC to consider the bids. The BEC could also not disqualify any bidder. It could simply make recommendations to the BAC who could in turn, also not disqualify any bidders. In casu, the BAC had to make recommendations to the municipal manager who had the power and authority to make the final award. ${ }^{95}$ The court in Entsha Henra BK $v$ Hessequa Munisipaliteit ${ }^{96}$ also confirmed that the decision to disqualify bidders is the prerogative of the municipal manager. The mayoral committee in this case excluded the applicant (an unsuccessful bidder) from future contract opportunities on the ground of bribery. The court held that the mayoral committee's decision to exclude the applicant was invalid. Only the municipal manager could take this decision. ${ }^{97}$

In addition to disqualification for the non-payment of municipal rates and taxes and municipal service charges, and for not complying with specified bid conditions, there are also other legislative grounds for the disqualification of bidders. Examples include (i) unsatisfactory performance under a previous public contract in the past 5 years provided that notice of such unsatisfactory

94 For the facts of the case, see section 3.2.2 supra.

95 Par 124-128.

96 Entsha Henra v Hessequa Munisipaliteit 2008 JDR 0455 (C). Hereafter Entsha Henra BK.

97 For more detailed discussion and analysis, see Bolton 2008 Local Government Bulletin. 
performance had been given to the bidder; ${ }^{98}$ (ii) the preferred bidder or any of its directors committed a corrupt or fraudulent act in competing for the particular contract; ${ }^{99}$ (iii) the preferred bidder or any of its directors abused the SCM system of the municipality or municipal entity or committed improper conduct with respect to such system; ${ }^{100}$ (iv) the preferred bidder or any of its directors has been convicted or fraud or corruption in the past 5 years, ${ }^{101}$ (v) the preferred bidder or any of its directors neglected, reneged on or failed to comply with a public contract in the past 5 years; ${ }^{102}$ and / or (vi) the preferred bidder or any of its directors has been listed in the Register for Tender Defaulters under section 9 of the Prevention and Combating of Corrupt Activities Act. ${ }^{103}$ Most of these grounds for disqualification have been considered elsewhere and will not be canvassed again. ${ }^{104}$ Suffice it to say that even though the MSCM Regulations do not expressly provide for this, it can be inferred from the Regulations that these matters should be checked by the BEC to enable it to make an informed decision when recommending a preferred bidder to the BAC.

\subsection{Bid adjudication committee}

In dealing with this committee the relevant legislative provisions will first be discussed. An analysis will then follow of the provisions relating to the

98 MSCM reg 38(1)(d)(ii). See Renaissance Security and Cleaning Services $v$ Rustenburg Local Municipality (1811/2007) [2008] ZANWHC 29 (19 August 2008). (The court held that MSCM reg 38(1)(d)(ii) is couched in peremptory terms. As such, it placed an obligation on the municipality to inform the applicant of its bad track record failing which the municipality could not rely on such bad track record as justification for refusing to award the bid to the applicant who was the highest scoring bidder. The court found that the municipality had failed to provide proof of communications with the applicant concerning its unsatisfactory performance under a previous contract and accordingly set aside the award of the bid to the second highest bidder). For more discussion and analysis, see Bolton 2009 Local Government Bulletin.

99 MSCM reg 38(1)(e).

100 MSCM reg 38(1)(g)(i).

101 MSCM reg 38(1)(g)(ii).

102 MSCM reg 38(1)(g)(iii).

103 Act 12 of 2004. Reg 38(1)(g)(iv).

104 See Bolton (n 16) ch 13. For disqualification on the ground of corruption, in particular, see Williams and Quinot 2007 SALJ. 
composition of the committee and the consideration of the BEC's report and recommendations.

\subsubsection{Legislative provisions}

The bid adjudication committee (BAC) must consider the report and recommendations of the BEC. ${ }^{105}$ Depending on the system of delegations in place, the BAC must either make a final award or it must make a recommendation to the municipal manager to make the final award. ${ }^{106}$ If the BAC does not make a final award or recommend a preferred bidder to the municipal manager, it must make another recommendation to the municipal manager as to how the relevant procurement should proceed. ${ }^{107}$ The membership of the BAC must be composed of at least 4 senior managers of the municipality or municipality, which must include the Chief Financial Officer / CFO (or if the CFO is not available another manager in the budget and treasury office who reports directly to the CFO and who is designated by the CFO), at least one senior SCM practitioner who is an official of the municipality or municipal entity, and a technical expert in the relevant field who is an official of the municipality or municipal entity if such expert exists. ${ }^{108}$ The municipal manager must appoint the chairperson of the $\mathrm{BAC}^{109}$ and if the chairperson is absent from a meeting, the members who are present must elect one of them to preside over the meeting. ${ }^{110}$

In considering the report and recommendations of the BEC, the BAC must act independently from the BEC. The MSCM Regulations prohibits a member of the BEC or an advisor or person assisting the BEC from being a member of the

105 Reg 29(1)(a). The BAC should also "consider and rule on all recommendations / reports regarding the amendment, variation, extension, cancellation or transfer of contracts awarded" (National Treasury 2006 www.finance.gov.zal par 2).

$106 \operatorname{Reg} 29(1)(b)(i)$.

107 Reg 29(1)(b)(ii).

108 Reg 29(2).

109 The National Treasury suggests that where possible, the chairperson of the BAC should be the CFO (National Treasury 2006 www.finance.gov.za/ par 3).

110 Reg 29(3). 
BAC. ${ }^{111}$ Since the BAC acts independently from the BEC, the BAC may reject the recommendation of the BEC and award the bid to another bidder. It is suggested that this could happen if, for example, the BAC is of the view that the BEC's recommendation does not sufficiently indicate that all relevant factors have been taken into account, and the recommendation does not symbolise a logical, justifiable conclusion based on all relevant information at the BEC's disposal. Prior to awarding the bid to the new preferred bidder, however, the BAC must check that the new preferred bidder's municipal rates, taxes and municipal service charges are not in arrears; and it must notify the municipal manager of its decision. ${ }^{112}$ The municipal manager may then, "after due consideration of the reasons for the deviation, ratify or reject the decision of the $[B A C] "{ }^{113}$ If the municipal manager rejects the decision of the BAC, he or she may refer the decision back to the BAC for reconsideration. ${ }^{114}$ Since the decision falls within the discretion of the municipal manager, however, he or she may also make the final award. In such a case the municipal manager must, in writing, within 10 working days notify the Auditor-General, the relevant provincial treasury and the National Treasury, and in the case of a municipal entity also the parent municipality, of the reasons for deviating from the decision of the BAC. ${ }^{115}$ There is, however, no duty to report if the decision of the $B A C$ is rejected in order to rectify an irregularity in the process. ${ }^{116}$ The

111 Reg 29(4).

112 Reg 29(5).

$113 \operatorname{Reg} 29(5)(b)(i)$.

114 Reg 29(5)(b)(ii).

115 Reg 29(7) read with s 114(1) of the MFMA.

116 S 114(2) of the MFMA. See Steytler and De Visser (n 1) 14-29 who note that s 114 of the MFMA "signals the ultimate distrust in the participation of the political organ of the municipality in the procurement process; the council is totally excluded from the decisionmaking and the municipal manager's decision is not subject to the review of the council. Oversight is then effected by external organs of state. In the case of the Auditor-General, compliance with the SCM policy (and the MFMA and [MSCM] Regulations) forms part of the annual audit and the report would invite special attention to the award of that tender. Should the National Treasury have any concerns, it may seek to stop a conditional grant if the funds are being used for the procurement. Within the constitutional scheme of supervision, the provincial treasury may be the only organ of state that may act decisively. It may exercise the province's general monitoring powers to examine the circumstances of the award and intervene where an executive obligation has not been met. The province may give a directive that the award may not be awarded if an executive obligation has not been complied with (for example, if one of the many procedural requirements has not been 
municipal manager moreover exercises a general supervisory role over the BAC (and also the BEC as noted above) and may at any stage of the bidding process refer a recommendation of the BAC back for reconsideration. ${ }^{117}$

\subsubsection{Composition of the BAC}

It is, of course, important for there to be no overlap in the membership of the BEC and BAC. It would simply be illogical for the same persons who make recommendations on the award a bid to also consider and approve those recommendations. In practice, it is foreseeable that it may be necessary for a member(s) of the BEC to present the BEC's report and recommendations to the BAC and to clarify any uncertainties. In doing so, however, it is important to ensure that such member(s) have no voting power on the BAC. ${ }^{118}$ The court in Actaris South Africa (Pty) Ltd further stressed the importance of having a technical expert as member of the BAC where such expert exists within the municipality. Actaris had argued that the BAC of the municipality was not properly composed; there was no indication that "any person serving on [the BAC] had technical expertise" as required by the municipality's SCMP and the MSCM Regulations. ${ }^{119}$ Actaris therefore effectively relied on MSCM Regulation 29(2)(iii) which provides, insofar as relevant, that "[a BAC] must consist of at least four senior managers of the municipality or municipal entity which must include - ... a technical expert in the relevant field who is an official of the municipality or municipal entity, if the municipality or municipal entity has such an expert". In this respect the court found that even though the Chief Electrical Engineer and the Chief Superintendent: Testing and Metering were "technical expert(s) in the relevant field", they were (also) not members of the BAC. ${ }^{120}$

met). If the municipal manager fails to comply with the directive, the province may resort to court action" (footnotes omitted).

117 Reg 29(6). See further National Treasury 2006 www.finance.gov.zal par 3-6 on the composition of the BAC and the appointment of members, the duties and powers of the various committee members, meeting procedures, and the conduct of committee members.

118 See also National Treasury 2006 www.finance.gov.zal par 4.5.

119 Par 35 in the case, emphasis original.

120 As noted in section 3.2.2, they were not members of the BEC.

80/168 
There was no reason why at least one of them could not be a member of the BAC and the other a member of the BEC. The court held that the phrase "if such an expert exists" in paragraph 28(2)(c) of the SCMP, which reiterates MSCM Regulation 29(2)(iii), is peremptory:

\begin{abstract}
When the provisions of that paragraph are viewed in context it is clear that, where such an expert official is available, he or she 'must' be appointed for the purposes of at least that particular meeting where a [bid] which falls within his or her field of expertise is going to be considered. ${ }^{121}$
\end{abstract}

The court held that the bids in casu were of a highly technical and specialised nature and the municipality failed to put forward any reason or explanation as to why the relevant peremptory provisions of the SCMP (and ultimately the MSCM Regulations) were not complied with. ${ }^{122}$ It was clear that this non-compliance "may have had a prejudicial effect on the activities of [the] committees and the conclusions reached by them". ${ }^{123}$ The fact that none of the members of the committees were from the electricity department also meant that a decision was made that affected the department in circumstances in which the department never had the opportunity to participate in such decision. The BAC also did not have the benefit of any technical explanations or advice. The court held that the municipality had an obligation to ensure that both the BEC and BAC were properly constituted and that decisions were properly taken. In casu, the municipal manager did not comply with the requirements for the appointment of the members and the composition of the committees. The result was that when the decisions were taken to disqualify Actaris for not meeting the functionality requirement in respect of one of the contracts and to award the three contracts to IMS, the BEC and BAC were not properly constituted. The court held that for these reasons alone the award of the contracts to IMS could be set aside because in terms of section 6(2)(b) of the Promotion of Administrative Justice

121 Par 64, emphasis original.

122 Referring to MSCM reg 28(2)(a) and 29(2)(iii).

123 Par 66. 
Act "mandatory and material" empowering provisions were not complied with. $^{124}$

\subsubsection{Consideration of the BEC's report and recommendations}

The BAC must consider the report and recommendations of the BEC and, in this respect, the judgment in Actaris South Africa (Pty) Ltd is once again relevant. The court focused in great detail on the proceedings of the BAC in this case and held that the BAC meeting had been convened and conducted with undue and inexplicable haste. The BEC meeting took place on the same day as the BAC meeting and concluded late in the afternoon. On the facts before the court it further appeared that the BAC meeting took place immediately after the BEC meeting with the result that the BAC meeting in all probability ended after normal office hours. Moreover, on the same day that the BAC made its recommendation to the municipal manager, the municipal manager "considered" it and made a final decision. The municipal manager also wrote a letter to IMS informing it of its success in the bid process the very same day. This too, the court held, would have been done after normal office hours and with seemingly undue haste. The members of the BAC were further led to believe that they had to come to a decision urgently. From the facts of the case, however, it was not clear why this was done. ${ }^{125}$ The court found that even though the requirement in bid procedures is for the BEC to meet first and to then make a recommendation to the $B A C$, the notice of the meeting of the BAC in casu stated that the meeting would commence at $14 \mathrm{~h} 00$ whereas the notice of the meeting of the BEC stated that that meeting would commence at $14 \mathrm{~h} 30$ the same day. It was also clear that only part of the proceedings of the BAC meeting was recorded. The municipal manager explained that the reason why the BAC met immediately after the BEC had concluded its meeting was "to expedite a tender decision" and because "[t]he contract with Actaris had already been extended twice and the continuation of this state of affairs was not 
desirable". ${ }^{126}$ The court found this explanation "improbable" and "extremely difficult" to believe because the contract with Actaris was extended on a monthto-month basis until the end of August 2007, which at the time was three months away. ${ }^{127}$ Actaris was also not informed of the outcome of its bid in the same urgent way as IMS was informed of its success.

The court, moreover, found that the BAC was not provided with a written report or recommendations by the BEC. On the facts before the court it appeared that at the meeting of the BAC, a member of the BEC (Mr B) was present and that he "highlight[ed] a few (conditions) that was (sic) mentioned" at the BEC meeting. ${ }^{128}$ The BAC was, in other words, not provided with the contents of the deliberations, conclusions and recommendations of the BEC. It also appeared that when questions were asked at the BAC meeting regarding the award of the contracts to IMS, such questions were never answered. At least one of the questions was of a technical nature and could not be answered because $\mathrm{Mr} B$, who represented the BEC at the BAC meeting, was not a "technical person". ${ }^{129}$ The court held that it was clear that the technical issue that was raised -

\begin{abstract}
bore serious financial and other implications and therefore the absence of a technical expert as a member (or at least technical input) at the meeting of the [BAC] obviously resulted in prejudice. Not only did it result in a decision being taken on a highly technical issue without the contribution or influence of the vote of an expert, but also the absence of technical advice and input resulted in the members and others who attended not being properly informed and not being able to properly apply their minds. ${ }^{130}$
\end{abstract}

The court found that the information provided by Mr B to the BAC "could by no stretch of the imagination be claimed to have amounted to an oral version of the 'report and recommendations' which the [BEC] had been supposed to submit and which the [BAC] had been supposed to consider". ${ }^{131}$ The court

126 Par 81, emphasis original.

127 Par 82.

128 Par 87, emphasis original.

129 Par 94, emphasis original.

130 Par 96.

131 Par 114, emphasis original. The court found no need to decide whether it was at all possible and in compliance with par 27(1)(d) and 29(1)(a) of the SCMP and Regulations 
concluded that without a report and a full version of the recommendations of the BEC, it would not have been possible for the BAC members to have had a meaningful discussion or, in reality, to properly apply their minds to the complicated technical issues and the huge financial implications involved in the bids. $^{132}$

The municipality had argued that even if the court decided that its decisions were reviewable, the court had to exercise its discretion against setting aside the decisions. The court, however, held that Actaris was entitled to have its bids properly evaluated and adjudicated. It would be reckless for the court to allow IMS to further execute the contracts in question when there were serious financial and technical matters that were on the face of it not considered in the award of the contracts. The court held that any possible prejudice that IMS may suffer was far outweighed by: the losses that the municipality would suffer if it is found that the costs of IMS's bids are significantly higher than would be necessary and justifiable; and the prejudice to Actaris through the unlawful rejection of its bids. The court accordingly set aside the three contracts awarded to IMS and ordered the municipality to reconsider the awards. The municipality and IMS had to pay the costs of Actaris' application jointly and severally. ${ }^{133}$

\subsection{The supervisory role of the municipal manager}

As noted above, the municipal manager is obliged to approve the bid specifications drafted by the BSC prior to the publication of the invitation for bids. ${ }^{134}$ The municipal manager also has a general supervisory role over the BEC and BAC. All three committees are, in other words, under the supervisory

29(1)(a) and 29(1)(b) of the MSCM Regulations for a BEC to "submit" and a BAC to "consider" an oral version of the BEC's report and recommendations for the award of a bid.

132 Par 118. See also National Treasury 2006 www.finance.gov.za/ par 4.4 which stipulates that "members of the BAC shall...apply their minds to matters at hand in order to take meaningful and accountable decisions".

133 Par 139-151.

134 MSCM reg 27(2)(g). 
control of the municipal manager. What precisely, however, is the extent of the municipal manager's supervisory role over the three committees? In particular, is the municipal manager entitled to make changes to the specifications, conditions or the rules that have been laid down for conducting the process such as qualification, selection or adjudication criteria, or procedural rules relating to formalities for bids? Is the municipal manager entitled to instruct the BEC and BAC to evaluate and adjudicate bids based on such changes? In answering these questions, the unreported case of Ninham Shand (Pty) Limited v Municipal Manager City of Matlosana and Others ${ }^{135}$ will be discussed, and suggestions will be made on the making of some of the changes mentioned.

\subsubsection{The facts and judgment in Ninham}

The municipality in Ninham called for bids for the appointment of consulting engineers for the design, bid documentation and project management for the construction of 14400 toilets in four different areas. The bid invitation provided that bids would be adjudicated in accordance with the municipality's SCMP, which was based on the Procurement Act and the BBBEEA. Bidders would score points as follows: 70 points for price, 20 points for functionality and 10 points for preference. A total of 26 bids were received and the BEC in its report to the BAC recommended the applicant as preferred bidder. On the facts of the case, however, it appears that the municipal manager was not satisfied with the point system used in the adjudication of bids and a letter was sent to all bidders proposing the use of a new point system. In terms of the new system, points would be allocated as follows: 30 points for specific project applicable expertise, 10 points for approach and methodology, 30 points for track record, 20 points for price and 10 points for empowerment. ${ }^{136}$ All the bidders, including

135 Ninham Shand v Municipal Manager City of Matlosana (25911/2007) [2008] ZAGPHC 113 (25 April 2008). Hereafter Ninham.

136 In principle, this allocation of points would comply with the Procurement Act and Regulations, specifically the 90/10 point system in terms of which 90 points are allocated for price and 10 for preference. It is generally accepted that 'price' would include factors such as expertise; track record; the nature, quality and reliability of the product or service to be rendered; or in this particular case, also approach and methodology. See further $85 / 168$ 
the applicant, were requested to provide the necessary information to facilitate the adjudication of bids based on the new criteria. The applicant and two other bidders objected to the use of the new criteria, arguing that there was not any valid reason for the amendment of the criteria and that the amendment was prejudicial to them. The bids were, however, re-adjudicated based on the new criteria. The applicant was again identified by the BEC as the highest scoring bidder, but in light of the timeframe for completing the project the BEC suggested a splitting of the bid between the four bidders scoring the highest points. ${ }^{137}$

When the splitting of the bid between the four bidders was communicated to them, the applicant objected thereto and argued that the bid should be awarded to it. The municipal manager then reasoned that under the circumstances there were valid and well-founded reasons to not award the bid and to re-advertise. All bidders who participated in the initial process were informed of the new bid invitation and the new criteria that would apply. The applicant did not participate in the new process and the bid was awarded to four bidders, that is, the third to sixth respondents. By the time the applicant approached the court for, inter alia, the review and setting aside of the municipal manager's decision to amend the adjudication criteria of the first call for bids and not to award the bid to the applicant, but to re-advertise and invite new bids, performance under the new contract was almost completed. The court reasoned, without giving judgment on the actions of the municipal manager, that the orders prayed for by the applicant, which included its appointment as preferred bidder under the first call for bids and the award of the bid to it, would result in chaos and prejudice to all the parties involved in the dispute as well as those not involved in the dispute but who are supposed to benefit from the project. The court noted that the applicant should have applied for an interdict at an earlier stage. ${ }^{138}$

section 3.2.1 on the meaning of the term "ability" with reference to the evaluation of bidders.

137 Page 6 of the transcript.

138 Pages 8-10 of the transcript. 


\subsubsection{Questions raised by Ninham and some suggestions}

The facts in Ninham raise questions on the precise extent of the municipal manager's supervisory role over the BSC, BEC and BAC. In particular, did the supervisory role of the municipal manager in Ninham entitle him to instruct the $B E C$ to re-evaluate the bids based on different adjudication criteria, that is, a new point system? After all, MSCM Regulation 27(2)(g), as explained above, placed an obligation on him to approve the bid specifications, and this would include the adjudication criteria and point system, before the advertisement for bids. ${ }^{139}$ Strictly speaking, therefore, he was not in a position to change the adjudication criteria after the opening and adjudication of bids. At the same time, it can be argued that there may be compelling or legitimate reasons for making such changes. One example may be where new budgetary constraints necessitate a cutback in the scope of the project. Another may be where the municipality or municipal entity, at the behest of the municipal manager, realises that it has omitted an important award criterion that could generate better value for money. Possibilities for changing award criteria may, however, result in abuse: award criteria may be changed after it has become clear that a "favoured" bidder would not win, or unreasonable and incorrect award criteria may be advertised to deter competition with the aim to change these after the receipt of bids. ${ }^{140}$

Neither the MFMA nor the MSCM Regulations deal expressly with the possibility of changes to the specifications, conditions or the rules that have been laid down for conducting the process such as qualification, selection or adjudication criteria, or procedural rules relating to formalities for bids. It is submitted that a distinction should be drawn between changes that are material and those that are non-material. ${ }^{141}$ The former would refer to changes that are

139 This point was also raised by the applicant in Ninham.

140 Arrowsmith Public and Utilities Procurement par 7.157.

141 See also Arrowsmith (n 140) par 7.158; R v Portsmouth City Council Ex parte George Austin (Builders) unreported judgment of 6 June 1995.

$87 / 168$ 
likely to have an impact on the identity of participating bidders and vice versa. If a municipality or municipal entity recognises the need to make a material change, it must return to a point in the bid process where it is certain that no prospective bidder is excluded because of the change. This suggestion is directly tied to the constitutional requirements of fairness, equity, transparency, competitiveness and cost-effectiveness in bid processes.

If regard is had to the nature and extent of the changes that were made in Ninham to the advertised point system, it is clear that the changes made were material. Whereas under the advertised point system, 70 points were allocated for price, 20 for functionality and 10 for preference, the new system allocated 30 points for specific project applicable expertise, 10 for approach and methodology, 30 for track record, 20 for price and 10 for empowerment. It is very likely that the new point system would have changed the identity of the participating bidders: new bidders may have participated and some of the already participating bidders may have decided not to participate. After adjudicating the bids based on the new point system, the municipal manager in Ninham of course decided to re-advertise for bids. The decision to re-advertise was, it is submitted, the correct approach (even though this decision was made only after the municipal manager tried to change the point system by communicating only with the existing participating bidders). The decision to readvertise ensured that new bidders were given an opportunity to participate, and gave effect to the requirements of fairness, equity, transparency, competitiveness and cost-effectiveness in bid processes. This does not however mean that re-advertisement is necessary in all cases, and that changes may never be communicated only to the participating bidders. If the changes made are non-material in that they are not likely to have an impact on the identity of participating bidders, the changes may be communicated only to participating bidders. An example of this may be where the original contract period advertised is extended by a few days. Such a change is unlikely to affect a contractor's decision to participate. Another example is where a municipality or municipal entity advertises a general request for proposals and thereafter restricts its bid invitation to a limited number of bidders. In such a case, 
information that was not disclosed in the general request for proposals may be changed by communicating the changes only to the participating bidders. ${ }^{142}$

\section{Conclusion}

In order for the different bid committees and the municipal manager to meet their obligations, it is important for committee members and the municipal manager to be familiar with and adhere to the relevant SCM legislation and to take heed of the National Treasury's guidelines and circulars. In light of recent court judgments, it is clear that the courts stress the importance of the roles and functions of the different committees. In Actaris South Africa (Pty) Ltd, the court reviewed and set aside three contracts awarded by the municipality, because the BEC and BAC were not properly constituted. The procedures within the two committees in evaluating and adjudicating the bids were also questionable. The judgment is important because it serves as a warning to municipalities to uphold and comply with the rules relating to the roles and composition of committees tasked with the evaluation and adjudication of bids. The rules relating to the appointment of committee members are there to ensure that, inter alia, the department that is directly affected by the outcome of the award has an opportunity to participate in the decision-making process. It is, as the court stated, crucial for the relevant department to play a role in the decisionmaking process. It is, moreover, important for the BAC to be assisted by a technical expert. This is particularly important in cases where the contract in question is of a highly technical nature. In those instances where a municipality fails to ensure that membership of the BAC includes a technical expert in the relevant field, it would have to prove that such an expert did not exist within the municipality. It is also peremptory for the BEC to submit a report and recommendations to the $\mathrm{BAC}$ for the award of a bid. In the end, the municipal 
manager has an obligation to ensure that the committees are properly constituted and that decisions are properly taken.

The court in Actaris South Africa (Pty) Ltd can be applauded for affording peremptory status to the relevant provisions of the municipality's SCMP and the MSCM Regulations, in particular Regulation 28(2)(a) with respect to the membership of the BEC and that membership must hail from the department requiring the goods or services; Regulation 28(1)(d) with respect to the submission of a report and recommendations by the BEC to the BAC; and Regulation 29(2)(iii) with respect to membership of the BAC (including that membership must include an expert in the relevant field unless such expert does not exist within the municipality). Affording peremptory status to the different provisions serves a number of important purposes. It enhances the integrity of bid procedures and promotes public confidence. Effect is also given to the intention of the legislature in enacting the provisions, and general compliance with the purpose of the MFMA and MSCM Regulations is encouraged.

The courts further stress the importance of the evaluation of bids in accordance with the bid specifications advertised, and for the contract with the preferred bidder to reflect such specifications. In Nelson Mandela Bay Municipality the court correctly set aside agreements concluded with the preferred bidder on the ground that they exceeded the scope of the bid invitation and the specifications advertised. The court in Ninham did not give judgment on the changing of the bid adjudication criteria by the municipal manager after the submission and evaluation of bids. As suggested, however, the decision of the municipal manager to re-advertise for bids was the correct approach. The changes made by him were material and could not be communicated only to the participating bidders.

The decision to disqualify bidders is, furthermore, as indicated by the courts in Actaris South Africa (Pty) Ltd and Entsha Henra BK the prerogative of the 
municipal manager. Neither a consultant, a municipal official, the BEC, BAC nor a mayoral committee can take this decision. 


\section{Bibliography}

Arrowsmith Public and Utilities Procurement

Arrowsmith S The Law of Public and Utilities Procurement $2^{\text {nd }}$ ed (Sweet \& Maxwell London 2005)

Bolton 2009 JSAL

Bolton $\mathrm{P}$ "The Status of Contracts Exceeding a Municipal Tender Call:

Nelson Mandela Bay Municipality v Afrisec Strategic Solutions (Pty) Ltd

2008 JDR 1014 (SE)" 2009 (2) Journal of South African Law 382-392

Bolton 2009 Local Government Bulletin

Bolton P "When Can Bidders with Bad Track Records be Rejected?" 2009 (11) Local Government Bulletin 22-24

Bolton 2008 Local Government Bulletin

Bolton P "Who Excludes Bidders from Future Contracts?" 2008 (10) Local Government Bulletin 22-25

Bolton Government Procurement in South Africa

Bolton P The Law of Government Procurement in South Africa (LexisNexis Butterworths South Africa 2007)

Gounden Affirmative Procurement Policy

Gounden SM The Impact of the Affirmative Procurement Policy on

Affirmable Business Enterprises in the South African Construction Industry (PhD thesis University of Natal 2000)

Penfold and Reyburn "Public Procurement"

Penfold G and Reyburn P "Public Procurement" in Chaskalson M et al (eds) Constitutional Law of South Africa $2^{\text {nd }}$ ed (Juta Cape Town 2003) 25-i $-25-36$ 
Schooner 2004 PPLR

Schooner S "The Paper Tiger Stirs: Rethinking Suspension and

Debarment" 2004 (5) Public Procurement Law Review 211-217

Steytler and De Visser Local Government Law

Steytler N and De Visser J Local Government Law of South Africa

(LexisNexis Butterworths South Africa 2007)

Trepte Public Procurement in the EC

Trepte P Public Procurement in the EC (CCH Europe 1993)

Watermeyer 2000 PPLR

Watermeyer R "The Use of Targeted Procurement as an Instrument of

Poverty Alleviation and Job Creation in Infrastructure Projects" 2000 (9)

Public Procurement Law Review 226-250

Williams and Quinot 2007 SALJ

Williams S and Quinot G "Public Procurement and Corruption: The South

African Response" 2007 (124) South African Law Journal 339-363

\section{Register of statutes and legislative instruments}

Broad-Based Black Economic Empowerment Act 53 of 2003

Constitution of the Republic of South Africa 1996

GN 868 in GG 27636 of 30 May 2005

GN R725 in GG 22549 of 10 August 2001

Local Government Laws Amendment Act 51 of 2002

Local Government: Municipal Finance Management Act 56 of 2003

Local Government: Municipal Structures Act 117 of 1998

Local Government: Municipal Structures Amendment Act 1 of 2003

Local Government: Municipal Systems Amendment Act 44 of 2003

Preferential Procurement Policy Framework Act 5 of 2000

Prevention and Combating of Corrupt Activities Act 12 of 2004 
Promotion of Access to Information Act 2 of 2000

Promotion of Administrative Justice Act 3 of 2000

\section{Register of cases}

Actaris South Africa (Pty) Ltd v Sol Plaatje Municipality, Intelligent Metering Systems (Pty) Ltd (1357/2007) [2008] ZANCHC 73 (12 December 2008) Entsha Henra BK v Hessequa Munisipaliteit 2008 JDR 0455 (C) Imvusu Trading 134 CC and Another v Dr Ruth Mompati District Municipality and Others (2628/08) [2008] ZANWHC 46 (20 November 2008)

Metro Projects CC and Another v Klerksdorp Local Municipality and Others 20041 SA 16 (SCA)

Millennium Waste Management (Pty) Ltd v Chairperson Tender Board:

Limpopo Province and Others [2008] 2 All SA 145 (SCA)

Minister of Social Development and Others v Phoenix Cash \& Carry - Pmb CC [2007] 3 All SA 115 (SCA)

Nelson Mandela Bay Municipality v Afrisec Strategic Solutions (Pty) Ltd 2008 JDR 1014 (SE)

Ninham Shand (Pty) Limited v Municipal Manager City of Matlosana and Others (25911/2007) [2008] ZAGPHC 113 (25 April 2008)

Ortlieb \& Associates v Camdeboo Local Municipal Council and Others 2005 JDR 0408 (E)

$R$ v Portsmouth City Council Ex parte George Austin (Builders) Ltd (6 June 1995) (unreported)

Renaissance Security and Cleaning Services CC v Rustenburg Local Municipality and Others (1811/2007) [2008] ZANWHC 29 (19 August 2008) Total Computer Services (Pty) Ltd v Municipal Manager, Potchefstroom Local Municipality and Others 20084 SA 346 (T)

\section{Register of internet sources}

National Treasury 2006 www.finance.gov.za/

National Treasury 2006 Guidelines for Municipal Bid Adjudication Committees MFMA Circular No 34 Supply Chain Management Issues $94 / 168$ 
Annexure B www.finance.gov.za/legislation/mfma/circulars/circular\%20

34.aspx [date of use 11 June 2009]

National Treasury 2005 www.treasury.gov.za/

National Treasury 2005 Supply Chain Management: A Guide for

Accounting Officers of Municipalities and Municipal Entities

www.treasury.gov.za/legislation/mfma/Default.aspx [date of use 11 June 2009]

UNCITRAL 1994 www.uncitral.org/

United Nations Commission on International Trade Law 1994 Model Law on Procurement of Goods, Construction and Services

www.uncitral.org/uncitral/en/uncitral texts/procurement infrastructure/1994

Model.html [date of use 29 Jan 2009]

WTO 1996 www.wto.org/

World Trade Organisation 1996 Government Procurement Agreement www.wto.org/english/tratop e/gproc e/gproc e.htm [date of use 29 Jan 2009]

\section{List of abbreviations}

BAC Bid adjudication committee

BBBEEA Broad-Based Black Economic Empowerment Act

BEC Bid evaluation committee

BSC Bid specification committee

CFO Chief Financial Officer

ch chapter(s)

KES Khatima Engineering Services

MFMA Local Government: Municipal Finance Management Act

MSCM Municipal Supply Chain Management

par paragraph(s)

PPLR Public Procurement Law Review

RDP Reconstruction and Development Programme

reg regulation(s)

$\mathrm{s}$ section(s) 
SCM Supply Chain Management

SCMP Supply Chain Management Policy

SOW scope of work (agreement)

UNCITRAL United Nations Commission on International Trade Law

WTO GPA World Trade Organisation Government Procurement Agreement 